\title{
Creative Intervention
}

\section{We the People...}

\author{
MESTIZO ARTS \& ACTIVISM COLLECTIVE \\ Salt Lake City, USA
}

We the People... was written and performed by the Mestizo Arts \& Activism (MAA) Collective (https://maacollective.org), a social justice think tank led by the urgent concerns of young people of color living on the West Side of Salt Lake City, Utah (USA). The piece was written at a time when political and public debate over immigration status, education, and geographic boundaries has become increasingly hostile, especially as Utah's $90 \%$ White majority has shifted over the last few decades. Because immigration issues are one of the most important concerns for youth researchers, one significant site for our activist research is the Utah State Capitol. During each legislative session, we follow proposed policies and discuss their implications and potential impacts upon our community. We write our representatives, track bills, attend committee hearings, and speak to legislators about our concerns. Within this time span, hundreds of anti-immigrant policies have been proposed, dominating the state's annual legislative session with xenophobic discourse that fans the fire of racism, "demonizing" immigrants as the main problem with balancing the state budget and overall economic crisis (Cahill, 2010; Cahill, Gutiérrez Alvarez \& Quijada Cerecer, 2015). Several of our participatory research projects were inspired by our experiences at the state capitol and address particular legislative concerns that affect our community. In February 2008, we co-created the site-specific spoken word piece, We the People, which MAA performed in the rotunda of the state capitol on the last night of the Utah State Legislative Session. Speaking to the ongoing struggles faced by our communities that are in stark relief today, the piece was inspired by our research and was another way that we shared our work with a broader public. ${ }^{1}$ The title of the piece, We the People, refers to the preamble of the

\footnotetext{
${ }^{1}$ Mestizo Arts and Activism Collective considers how the arts might provide a social and shared context for challenging racialized characterizations by engaging community-based participatory action research for social change (see Quijada Cerecer, Cahill, González Coronado \& Martinez, 2019).
}

Correspondence Address: David Quijada, Ethnic Studies Program, Saint Mary’s College of California, Moraga, CA, 94575; Email: daq2@stmarys-ca.edu 
U.S. Constitution. In an effort to complicate the said inclusive and just declaration of "We the People," MAA youth researchers rearticulated what "We the People" means based on their personal, familial, and communal lived experiences with immigration debates and policies.

The following transcript is read by 10 youth researchers who organize themselves into two opposing groups: residents of the Westside (Alberto, Vicky, Erica, Antonia and Octavio) and the Corporates (Amanda, Azucena, Theresa, Daniel and Lorenzo). Pseudonyms have been used for youth researchers.

(Octavio) We the people of the Westside!

(WR ${ }^{2}$ : Erica \& Antonia) Las SUPA cholas of love. ${ }^{3}$

(WR) We the people of the Westside!

(WR: Alberto) We from your so-called "shadow" lands... My home... My pride land... Come one... Come all. Welcome home, homes!

(WR: Octavio \& Alberto) Home sweet home (shake hands).

(WR: Alberto) We are the familia, the people. We the familia who cares and has each other's back. We the ones that regulate.

(WR: Vicky, Erica \& Antonia) The Sista cholas of love.

$\left(\mathrm{C}^{4}\right.$ : Amanda, Azucena, Theresa, Daniel \& Lorenzo) walk toward the Westside Residents (Alberto, Vicky, Erica, Antonia, \& Octavio) - creating spatial divide and representing the rupture of safety - threatening body language.

(C: Amanda) We the people (the Corporates) we've come to tell you what to do and how to live. It's not my fault that you guys just can't do everything we do and how we do it. That is the reason why we get lobbyists to change laws to fit our needs not yours.

\footnotetext{
${ }^{2} \mathrm{WR}=$ Westside Residents.

${ }^{3}$ The super cholas of love. Chola (singular) or Cholas (plural) is a reclaimed urban Latina identifier that in this context connotes a familial affiliation beyond street gang culture. ${ }^{4} \mathrm{C}=$ The Corporates.
} 
(C: Azucena) We own your labor and know that you need the money... So, go ahead and quit if you don't like the health plan... There's a person behind you, waiting to replace you! Not to worry - we got your interest in mind - so sit back, relax and let us take control.

(C: Theresa) We who started off by putting chains on ankles and wrists, and stole dirt and earth even though it was a gift. We who re-sell what you build and break your backs in the field so our green eyes of dead presidents can keep slavery alive, and if you don't do your time in our factory then were sure we have one of your family doin' time in the yard without salary.

Westside Residents speak in protest and with assertive voice.

(WR: Erica) You call us gangsters and yet you have come to change laws that only profit you...

(WR: Antonia) You call us gangsters and yet you have come to raid our minds with your ideas and your ideas only... and sequester our power.

(WR: Alberto) You are the wall of White middle class, heterosexual males that keep us from our rights, only willing to jump ${ }^{5}$ us in if we conform to your ideas.

(WR: Vicky) You are the gangsters who masquerade behind suitcases and ties, who sit behind the bougie ${ }^{6}$ appeal of your seats ... complain at defeats and seek the demise of those who challenge you. You are the blue and the red - Republican and Democrat. The gangsters who hide behind suits and ties... telling us ALLLLLLLLLLLL lies.

In retort, two Corporates (Lorenzo \& Daniel) - who turn out to be undercover intergalactic aliens in shades and suits - speak.

(C: Lorenzo) You don't know who I am. I am more than you. What makes you think we are equal?

(C: Daniel) We are those beings who observe and experiment with laws because we know we shall fly free of our own decision and their consequences. Who no doubt can reconvene, clean the board and start all over, again... and again....

\footnotetext{
${ }^{5}$ A slang term used to initiate someone into a street gang.

${ }^{6}$ Abbreviated version of bourgeoisie.
} 
All Corporate performers, including the undercover intergalactic aliens, unmask themselves (remove sunglasses), ending their performance as corporates. Now all ten performers collectively speak to the audience.

(Lorenzo) We the people of color... the purples, blacks, yellows, browns, and reds... yes don't forget the reds!

(Antonia) The people con sabor en la sangre! ${ }^{7}$

(Daniel) We have abandoned the shadow to proudly speak our minds. To challenge the "commonsense" that claims we are apathetic and careless.

(Erica) It is obvious we will not melt into the pot, but rather will savor our flavors in a pico de gallo bowl.

(Octavio) We are most importantly the people who make up Utah.

(Azucena \& Theresa) We are loyal and hardworking citizens who are not represented and listened to.

(Amanda) I am a sister.

(Alberto) A brother.

(Vicky) A mother.

(Alberto) A father.

(Octavio) And I am them and they are me.

(Lorenzo) We all smile, we all cry.

(Erica) We share the same land, breathe the same air, live on the same soil. Why are we not treated the same?

(All Performers) We have come - our time is now! Today! Not yesterday!

(Antonia) We are rejecting the crumbs we have been given and demand that we be given a piece of the pie - a piece with which we will nourish our communities and counteract the hunger we have been plagued with.

(Octavio) We are hungry! Hungry for change!

\footnotetext{
${ }^{7}$ Literally translated as flavor in the blood, which in this context represents the performers' collective identity as people of color.
} 


\section{(All ten performers) Meaningful change!}

\section{References}

Cahill, C. (2010). "Why do they hate us?" Reframing immigration through participatory action research. Area, 42(2), 152-161.

Cahill, C., Gutiérrez Alvarez, L., \& Quijada Cerecer, D. A. (2015). A dialectic of dreams and dispossession: The school-to-sweatshop pipeline. Cultural Geographies, 23(1), 121-123.

Quijada Cerecer, D. A., Cahill, C., González Coronado, Y. S., \& Martinez, J. (2019). “We the People": Epistemological moves through cultural praxis. Cultural Studies-Critical Methodologies, 19(3), 214-221. 